\title{
Severe Lateral Thoracic Fracture-Dislocation without Neurological Deficit - Case Report
}

\section{Fratura torácica com luxação lateral grave sem déficit neurológico - relato de caso}

\author{
Catarina C. Lins ${ }^{1}$ Diego T. do Prado ${ }^{2}$ Andrei F. Joaquim ${ }^{1,3}$ Yvens B. Fernandes ${ }^{1,3}$ Paulo A. T. Kimaid ${ }^{4}$ \\ ${ }^{1}$ Division of Neurosurgery, Hospital Municipal Dr. Mario Gatti, \\ Address for correspondence Catarina Couras Lins Toniolo Do Prado, \\ Campinas - SP, Brazil \\ 2 Clinics Hospital, Faculdade de Medicina, Universidade de São Paulo, \\ MD, Hospital Municipal Dr. Mario Gatti, Rua Sócrates, 407, São Paulo, \\ São Paulo, São Paulo, Brazil \\ ${ }^{3}$ Department of Neurology, Universidade Estadual de Campinas - \\ Unicamp, São Paulo, Brazil \\ ${ }^{4}$ Department of Clinical Neurology, Division of Neurophysiology, \\ Universidade Estadual de Campinas - Unicamp, Campinas, Brazil \\ Arq Bras Neurocir 2016;35:244-247.
}

\begin{abstract}
Keywords

- spinal fractures

- dislocations

- thoracic vertebrae

- surgical procedures
\end{abstract}

Introduction A case report of a thoracic fracture-dislocation (T11-T12) without neurological deficit is presented.

Objective Report the diagnosis and treatment of a traumatic severe fracture with lateral dislocation at the thoracolumbar junction without neurological deficit.

Background Fracture-dislocation of the thoracic spine without neurological deficit is a rare lesion. We retrieved only 15 cases reported in the literature. Surgical treatment with spinal decompression, fusion and realignment is the treatment of choice.

Case A 40-year-old man suffered a bicycle accident and was admitted with severe back pain but neurologically intact. He was treated with a wide laminectomy and spinal cord decompression followed by correction of his deformity using pedicle screw instrumentation and rod maneuvers.

Results After three days, the patient was able to walk, and after one month he had just mild back pain, but was neurologically intact, and was able to return to his usual daily activities. After six months, he was neurologically intact and performing routine physical activities.

Conclusions Fracture-dislocation of the thoracic spine without neurological deficit is a rare injury. A good outcome can be obtained with modern spinal stabilization surgical techniques, avoiding late neurological deterioration. received

November 24, 2015

accepted

August 4, 2016

published online

September 17, 2016
DOI http://dx.doi.org/

$10.1055 / \mathrm{s}-0036-1592104$. ISSN 0103-5355.
Copyright $\odot 2016$ by Thieme Publicações License terms

Ltda, Rio de Janeiro, Brazil 


\section{Resumo}

\section{Palavras-Chave}

- fraturas de coluna

- luxações

- vértebras torácicas

- procedimentos cirúrgicos
Introdução Apresentamos um relato de caso de fratura-luxação torácica (T11-T12) com grande deslocamento lateral entre os corpos vertebrais, sem déficit neurológico. Objetivo Relatar o diagnóstico e tratamento de uma fratura-luxação grave na junção toracolombar com preservação da função neurológica.

Dados Fratura-luxação da coluna torácica sem déficit neurológico é uma lesão rara. Apenas 15 casos relatados na literatura foram encontrados em nossa revisão. $\mathrm{O}$ tratamento de escolha se faz com descompressão medular, realinhamento e estabilização.

Caso Um homem de 40 anos sofreu um acidente de bicicleta e foi admitido com dorsalgia severa, mas neurologicamente intacto. Ele foi tratado com ampla laminectomia e descompressão medular e, depois, correção da deformidade com parafusos pediculares lombares e manobras de realinhamento.

Resultados Após três dias, o paciente estava apto a caminhar, e após um mês, tinha apenas leve dorsalgia e estava neurologicamente intacto, podendo retomar suas atividades de vida diária. Após seis meses da cirurgia, mantinha-se neurologicamente estável e realizando atividades físicas regularmente.

Conclusão Fratura-luxação com deslocamento vertebral grave da coluna torácica sem déficit neurológico é uma lesão rara. Um bom desfecho pode ser obtido com técnicas modernas de estabilização da coluna e redução da lesão, evitando deterioração neurológica.

\section{Introduction}

The thoracolumbar junction is located between the relatively stable thoracic spine and the mobile lumbar spine. This may lead to a predisposition to certain types of traumatic injuries. ${ }^{1,2}$ The thoracic spine is rigidly stabilized by anterior and posterior longitudinal ligaments, by the ribs, with their costotransverse ligaments and their articulation with the manubrium and the spine, by the ligamentum flavum, and the sagittal orientation of joints wich resists axial rotation and horizontal translation. ${ }^{3-6}$ Because of that, it takes a great force to cause a fracture dislocation in the thoracic spine. Thoracic fractures with displacement in which the neurological status is normal or near normal are rare. This type of injury leads to complete paraplegia in $80 \%$ of cases. ${ }^{3,5}$ Cases of thoracic trauma with fracture type $\mathrm{C}$ in which neurological function is normal, as demonstrated in this case, are even rarer. In this report, we present one case of rotational traumatic fracture and lateral dislocation (AOSpine - type C) involving the thoracic spine, and discuss the surgical strategies used to manage it.

\section{Case}

This 40-year-old man was bicycling when he was hit by a car. He was brought to the emergency unit with severe pain in his back and left leg. Neurological examination showed no evidence of motor or sensitive deficits. After clinical evaluation, a thoracolumbar computed tomography (CT) scan was performed, as shown in - Fig. 1.
A T11-T12 severe fracture-dislocation - classified as a type C injury according to the new AO Classification System was the diagnosis. ${ }^{7,8}$ His Thoracolumbar Injury Classification System score was of 6 points ( 3 for rotational, 3 for posterior ligamentous complex injury, and 0 for neurological status), and surgical treatment was then indicated. ${ }^{9}$ He also had pedicle and laminar fractures (-Fig. 1). The spinal canal was "opened" by the lamina fractures, and that potentially explained the neurological preservation (-Fig. 1).

Surgical procedure: an intraoperative neurophysiology monitoring standard protocol with lower limb Somatosensory Evoked Potentials (SEP) and lower and upper limb Transcranial Motor Evoked Potential (TCMEP) was applied. A wide laminectomy with concomitant facetectomies from T11-T12 was performed to avoid a new compression in the reduction maneuver and release the spine. Pedicle screws were inserted at T10-T11 and L1-L2 bilaterally. A temporary spinal rod was connected at the right T10-T11 screws, and another was used at the right L1-L2 screws. Distraction of the segment with manual reduction and spinal realignment was then performed, checking for TCMEP. A definitive rod was then inserted at the left T10-L2 screws, and the temporary right rods were removed. Finally, a definitive rod was attached on the right side (-Fig. 2-intraoperative view). Bone graft harvest from the laminectomies and the facet joints were used for a posterolateral fusion.

Normal values of SEP and TCMEP obtained before surgery were maintained until the end of the surgery without significant change. After the procedure, the patient was neurologically intact. He was able to walk three days after 


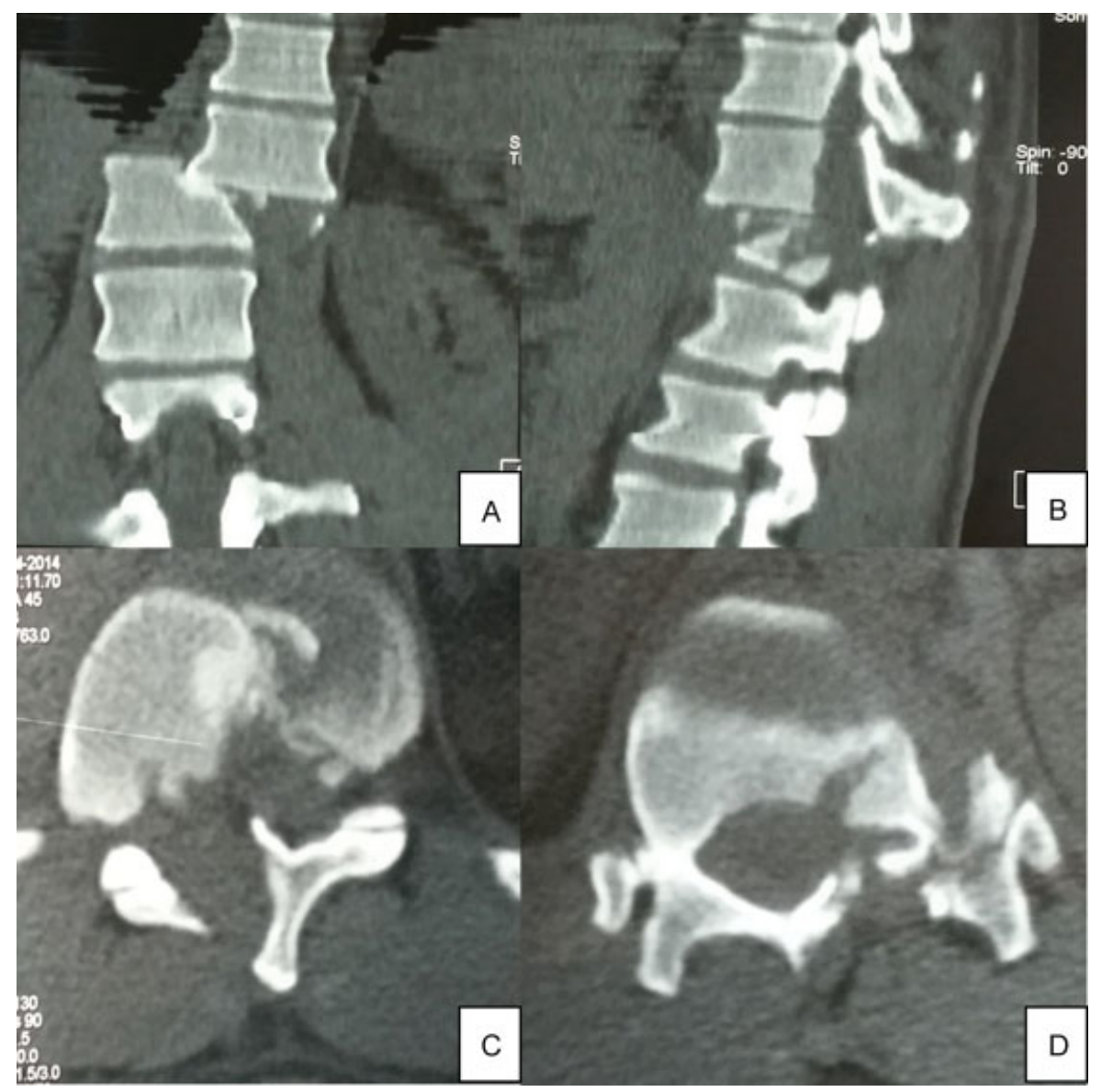

Fig. 1 A computed tomography (CT) scan showing complete lateral dislocation between T11 and T12 in the coronal (A), sagittal (B) and axial (C and D) images. In C, the spinal canal was "opened," and that potentially explained why this patient had neurological preservation.

surgery, and was discharged to his home on the eighth day. After six months, he had some mild occasional pain, but was able to practice physical activities, and was neurologically intact.

\section{Discussion}

We retrieved in our literature review just 15 well-documented cases of fracture-dislocation of the thoracic spine in which the neurological function was demonstrated as normal or near normal. ${ }^{3,10-20}$

By definition, fracture-dislocation involves the disruption of all the elements of the spine. ${ }^{1,21}$ Bohler subdivided fracture-dislocation in translational or rotational displacement without lamina and pedicle fracture, which was associated with a high incidence of paraplegia. ${ }^{4}$ The majority of fractures and dislocations of the thoracic spine with spinal cord preservation are located between T6 and T9. ${ }^{15}$ This fact

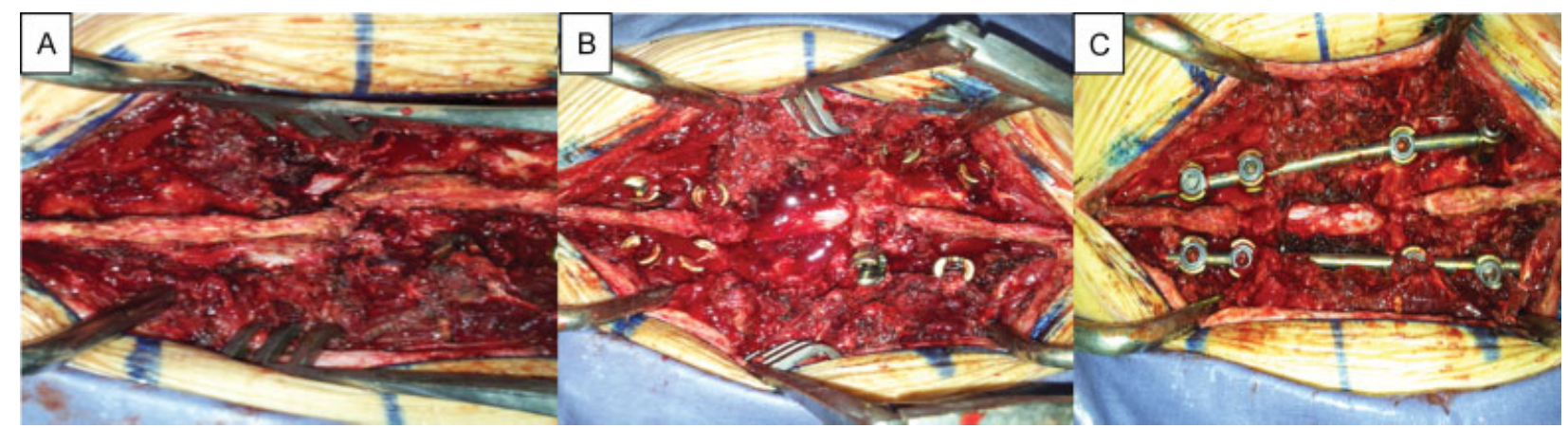

Fig. 2 Intraoperative view of the thoracic spine injured after muscular dissection (A); after T11-T12 laminectomy and screw insertion (B); and after correction of the dislocation with rod connection (C). 
occurs because in this area the spinous processes extend inferiorly more than any other segment of the spine. Consequently, high shear forces would be concentrated in the middle column, leading to fractures of both pedicles and preservation of the spinal canal, ${ }^{16}$ in accordance with what occurred in our presented case. Twenty percent of the injuries described in the original series of Denis ${ }^{6}$ were fracture-dislocation, with the majority having occurred at the thoracolumbar junction. Fracture-dislocation is further characterized in shear, bending-rotation or flexion-distraction. According to the Thoracolumbar Injury Classification and Severity Score (TLICS), fracture-dislocation (translational serious injury with disruption of the posterior ligamentous complex with or without neurological deficit) is considered a very unstable injury. ${ }^{7,22-25}$ The correct management of thoracolumbar spine trauma involves multiple steps, such as precise diagnosis, classification, and treatment. ${ }^{26,27}$

Operative techniques for this spinal injury must provide options for distraction of the impacted vertebral bodies, restoration of sagittal and coronal misalignments, and maintenance of correction with stable segmental internal fixation. Vertebral body and laminar spreading instruments are extremely useful in vertebral element distraction and restoration of alignment. ${ }^{1}$ The surgical technique includes: spinal cord wide decompression to avoid injury during realignment, and also "release" of the spine for realignment; instrumentation with pedicle screws; correction of the deformity and misalignment using rod maneuvers, such as temporary rods; and posterolateral arthrodesis for fusion.

Fracture-dislocation of the thoracic spine without neurological deficit is a rare injury. In this case, we have attributed the neurological preservation to the fact that the fracture "opened" the spinal canal. A good outcome can be obtained with modern spinal stabilization surgical techniques.

\section{References}

1 Yadla S, Lebude B, Tender GC, et al. Traumatic spondyloptosis of the thoracolumbar spine. J Neurosurg Spine 2008;9(2):145-151

2 Sekhon LH, Fehlings MG. Epidemiology, demographics, and pathophysiology of acute spinal cord injury. Spine 2001;26(24, Suppl)S2-S12

3 Shapiro S, Abel T, Rodgers RB. Traumatic thoracic spinal fracture dislocation with minimal or no cord injury. Report of four cases and review of the literature. J Neurosurg 2002;96(3, Suppl)333-337

4 Bohler L. Technik der Knochenbruchbehandlung im Frieden und im Kriege. Maudrich, Berlin 1943: 9-11

5 Bohlman HH, Freehafer A, Dejak J. The results of treatment of acute injuries of the upper thoracic spine with paralysis. J Bone Joint Surg Am 1985;67(3):360-369

6 Denis F. The three column spine and its significance in the classification of acute thoracolumbar spinal injuries. Spine 1983;8(8):817-831

7 Vaccaro AR, Oner C, Kepler CK, et al; AOSpine Spinal Cord Injury \& Trauma Knowledge Forum. AOSpine thoracolumbar spine injury classification system: fracture description, neurological status, and key modifiers. Spine 2013;38(23):2028-2037

8 Joaquim AF, Patel AA. Relationships between the Arbeitsgemeinschaft für Osteosynthesefragen Spine System and the Thoraco- lumbar Injury Classification System: an analysis of the literature. J Spinal Cord Med 2013;36(6):586-590

9 Vaccaro AR, Lehman RA Jr, Hurlbert RJ, et al. A new classification of thoracolumbar injuries: the importance of injury morphology, the integrity of the posterior ligamentous complex, and neurologic status. Spine 2005;30(20):2325-2333

10 de Lucas JC, Alvarez L, Abril JC, Calvo E. Fracture-dislocation of the thoracic spine without neurological lesion. Injury 1994;25(2): 105-107

11 Gertzbein SD, Offierski C. Complete fracture-dislocation of the thoracic spine without spinal cord injury. A case report. J Bone Joint Surg Am 1979;61(3):449-451

12 Hanley EN Jr, Eskay ML. Thoracic spine fractures. Orthopedics 1989;12(5):689-696

13 Harryman DT. Complete fracture-dislocation of the thoracic spine associated with spontaneous neurologic decompression. A case report. Clin Orthop Relat Res 1986;(207):64-69

14 Korovessis P, Sidiropoulos P, Dimas A. Complete fracture-dislocation of the thoracic spine without neurologic deficit: case report. J Trauma 1994;36(1):122-124

15 Liljenqvist U, Halm H, Castro WH, Mommsen U. Thoracic fracturedislocations without spinal cord injury: a case report and literature review. Eur Spine J 1995;4(4):252-256

16 Miyasaka Y, Satomi K, Sugihara S, Tahara Y, Hayashi T, Ishii Y. Posterior fracture-dislocation of the thoracic spine without neurologic deficit. A case report and short literature review. Spine 1993;18(15):2351-2354

17 Sasson A, Mozes G. Complete fracture-dislocation of the thoracic spine without neurologic deficit. A case report. Spine 1987;12(1): 67-70

18 Simpson AH, Williamson DM, Golding SJ, Houghton GR. Thoracic spine translocation without cord injury. J Bone Joint Surg Br 1990; 72(1):80-83

19 Uriarte E, Elguezabal B, Tovio R. Fracture-dislocation of the thoracic spine without neurologic lesion. Clin Orthop Relat Res 1987;(217):261-265

20 Weber SC, Sutherland GH. An unusual rotational fracture-dislocation of the thoracic spine without neurologic sequelae internally fixed with a combined anterior and posterior approach. J Trauma 1986;26(5):474-479

21 Vaccaro AR, Kim DH, Brodke DS, et al. Diagnosis and management of thoracolumbar spine fractures. J Bone Joint Surg Am 2003; $85: 2456-2470$

22 Joaquim AF, Fernandes YB, Cavalcante RAC, Fragoso RM, Honorato DC, Patel AA. Evaluation of the thoracolumbar injury classification system in thoracic and lumbar spinal trauma. Spine 2011;36(1): 33-36

23 Joaquim AF, Ghizoni E, Tedeschi H, Batista UC, Patel AA. Clinical results of patients with thoracolumbar spine trauma treated according to the Thoracolumbar Injury Classification and Severity Score. J Neurosurg Spine 2014;20(5):562-567

24 Joaquim AF, Lawrence B, Daubs M, et al. Measuring the impact of the Thoracolumbar Injury Classification and Severity Score among 458 consecutively treated patients. J Spinal Cord Med 2014;37(1):101-106

25 Joaquim AF, Daubs MD, Lawrence BD, et al. Retrospective evaluation of the validity of the Thoracolumbar Injury Classification System in 458 consecutively treated patients. Spine J 2013;13(12):1760-1765

26 Joaquim AF, Patel AA. Thoracolumbar spine trauma: Evaluation and surgical decision-making. J Craniovertebr Junction Spine 2013;4(1):3-9

27 van Middendorp JJ, Patel AA, Schuetz M, Joaquim AF. The precision, accuracy and validity of detecting posterior ligamentous complex injuries of the thoracic and lumbar spine: a critical appraisal of the literature. Eur Spine J 2013;22(3):461-474 